\title{
Induction of Cell Death in Transgenic Plants Expressing a Fungal Glucose Oxidase
}

\author{
Kemal Kazan, ${ }^{1,2}$ Fiona R. Murray, ${ }^{3}$ Ken C. Goulter, ${ }^{2}$ Danny J. Llewellyn, ${ }^{3}$ and John M. Manners ${ }^{1,2}$ \\ ${ }^{1}$ CSIRO, Division of Tropical Agriculture, Cunningham Laboratories, 306 Carmody Road, St. Lucia, QLD. \\ 4067, Australia; ${ }^{2}$ Cooperative Research Centre for Tropical Plant Pathology, John Hines \\ Building, University of Queensland, Brisbane, QLD. 4072, Australia; ${ }^{3} \mathrm{CSIRO}$, Division of Plant Industry, \\ P.O. Box 1600, Canberra, ACT, 2601, Australia \\ Accepted 20 February 1998.
}

Hydrogen peroxide $\left(\mathrm{H}_{2} \mathrm{O}_{2}\right)$ has been implicated in the induction of plant defense genes and programmed cell death. Expression of a chimeric fungal glucose oxidase (GO) gene driven by a pathogen- and wound-inducible promoter was evaluated in transgenic tobacco and canola as a possible tool for engineering plant cell death and defense gene induction. Expression of this gene under the control of a peroxidase gene promoter resulted in the accumulation of relatively low levels of $\mathrm{H}_{2} \mathrm{O}_{2}$ in the young leaves of transgenic tobacco plants and this was not sufficient to cause any visible cell death and defense gene induction as measured by PR-1a mRNA induction. Older leaves of transgenic tobacco plants, however, exhibited visible necrotic lesions and constitutively expressed PR-1a mRNA when grown under high light conditions. Inoculation of cotyledons of control and transgenic canola with Leptosphaeria maculans resulted in rapid cotyledon senescence in the transgenic plants. Strong activators of the peroxidase promoter, i.e., wounding and inoculation of transgenic plants with Cercospora nicotianae, were not sufficient to trigger any additional visible cell death in transgenic tobacco plants, compared with controls. However, when exogenous glucose was supplied to transgenic tissue, massive cell death and PR-1a gene induction were observed in tobacco. Exogenously applied salicylic acid further increased the rate and extent of cell death. Our results suggest that efficacy of GO expression for the induction of cell death is restricted by glucose supply in the plants and are consistent with a role for salicylic acid in the potentiation of plant cell death by $\mathrm{H}_{2} \mathrm{O}_{2}$.

Additional keywords: Brassica napus, Nicotiana tabacum.

Plants defend themselves from invading pathogens by activating a number of defense responses, which may include the reinforcement of cell wall components (Bradley et al. 1992), the synthesis of phytoalexins (Devlin and Gustine 1992), and the activation of numerous defense-related genes (Ward et al. 1991). One rapidly activated resistance mechanism of plants is the hypersensitive response (HR) (Jones and Dangl 1996). The HR has been postulated to be an outcome of the oxidative

Corresponding author: John M. Manners

E-mail: J.Manners@tpp.uq.edu.au burst or rapid production of active oxygen species (AOS) such as superoxide anions $\left(\mathrm{O}_{2}^{-}\right)$, hydroxy radicals $\left(\mathrm{OH}^{-}\right)$and hydrogen peroxide $\left(\mathrm{H}_{2} \mathrm{O}_{2}\right)$ (Levine et al. 1994; Baker and Orlandi 1995). The generation of AOS is among the earliest detectable responses of plant cells treated with pathogen elicitors, and precedes plant cell death (Baker et al. 1993; Doke and Ohashi 1988). Although several enzyme systems, including plasma membrane NADPH oxidases (Mehdy 1994; Desikan et al. 1996), peroxidases and lipoxygenases (Low and Merida 1996), and alternative oxidase (Wagner 1995), have been implicated in the production of AOS, it is currently unclear which mechanism is the predominant source of AOS leading to HR in plant-pathogen interactions.

Studies with cultured soybean cells suggested that exogenous $\mathrm{H}_{2} \mathrm{O}_{2}$ can activate a physiological programmed cell death (PCD) or apoptosis characterized by fragmentation of DNA into large (approximately $50 \mathrm{~kb}$ ) fragments, cell shrinkage, plasma membrane blistering, and nuclear condensation, all of which are also hallmarks of apoptosis in animal systems (Levine et al. 1996). The concentrations (2 to $10 \mathrm{mM}$ ) of exogenous $\mathrm{H}_{2} \mathrm{O}_{2}$ required to trigger apoptosis in cultured plant cells were much higher than those estimated to be generated endogenously during the $\mathrm{HR}$, and it has been suggested that such high concentrations of exogenous $\mathrm{H}_{2} \mathrm{O}_{2}$ may cause cell death by oxidative stress rather than by triggering apoptosis (Low and Merida 1996). Therefore, results from such studies should be extrapolated cautiously when drawing conclusions about the role of $\mathrm{H}_{2} \mathrm{O}_{2}$ as a signal for PCD at the whole plant level.

In addition to the induction of the $\mathrm{HR}, \mathrm{H}_{2} \mathrm{O}_{2}$ has also been implicated in a number of other plant defense responses, including construction of defensive barriers (Bradley et al. 1992), activation of phytoalexins (Apostol et al. 1989), and the production of the defense regulator salicylic acid (SA) (León et al. 1995). Recently, $\mathrm{H}_{2} \mathrm{O}_{2}$ has been further implicated as a secondary signal in the induction of systemic acquired resistance (SAR) by SA (Chen et al. 1993) and 2,6-dichloro isonicotinic acid (INA) (Conrath et al. 1995). However, the role of $\mathrm{H}_{2} \mathrm{O}_{2}$ as a secondary messenger in the SAR signaling pathway has not yet been conclusively demonstrated, as Bi et al. (1995) and Neuenschwander et al. (1995) have independently provided evidence that $\mathrm{H}_{2} \mathrm{O}_{2}$ levels in the tissue undergoing SAR are not elevated and induction of a pathogenesisrelated (PR) protein gene (PR-1a) could be due to the cell 
death caused by high concentration of externally applied $\mathrm{H}_{2} \mathrm{O}_{2}$.

From results obtained in some of the literature described above, one could predict that increases in endogenous $\mathrm{H}_{2} \mathrm{O}_{2}$ should lead to plant cell death and the activation of defense genes. Transgenic plants with reduced catalase activity (and therefore presumed increased endogenous $\mathrm{H}_{2} \mathrm{O}_{2}$ concentrations) showed elevated defense gene expression and cell necrosis in high light intensities where AOS would be generated (Chamnongpol et al. 1996). An alternative approach to the manipulation of endogenous concentrations of $\mathrm{H}_{2} \mathrm{O}_{2}$ is the expression of heterologous glucose oxidase (GO) genes in plants (Wu et al. 1995). Leaves of transgenic potato plants containing a chimeric GO gene of Aspergillus niger with expression driven by the cauliflower mosaic virus (CaMV) $35 \mathrm{~S}$ promoter had $\mathrm{H}_{2} \mathrm{O}_{2}$ concentrations two- to threefold higher than those of nontransgenic controls and were also more resistant to infections by Phytophthora infestans. However, effects of expression of this GO gene on plant cell viability and the induction of defense genes were not reported in this previous study. The present research was undertaken to test whether expression of a heterologous GO gene in transgenic plants has the potential to activate cell death and induce plant defense genes. The GO gene was derived from the fungus Talaromyces flavus and was expressed in transgenic tobacco and canola in a construct where expression was driven by a peroxidase $(\mathrm{Px})$ gene promoter that is weakly expressed constitutively but is highly responsive to infection by fungal pathogens and wounding (Curtis et al. 1997). We envisaged that this gene would permit an assessment of the potential of GO as a tool for engineering hypersensitivity and defense gene induction in transgenic plants. The results indicate that $\mathrm{GO}$ expression can induce cell death and defense gene induction and this effect of the transgene is further potentiated by exogenous SA. However, with this gene construct, the efficacy of GO expression for generating plant cell death and activating defense genes appears to be limited by glucose supply in the plant.

\section{RESULTS AND DISCUSSION}

\section{Expression of fungal GO in transgenic plants.}

To test whether a controlled cell death could be induced through the action of $\mathrm{H}_{2} \mathrm{O}_{2}$, we generated transgenic tobacco and canola lines expressing a GO gene isolated from a biocontrol fungus, Talaromyces flavus. GO ( $\beta$-D-glucose: oxygen 1-oxido-reductase, E.C.1.1.3.4) catalyzes the oxidation of glucose to gluconate and $\mathrm{H}_{2} \mathrm{O}_{2}$. Constitutive expression of $\mathrm{GO}$ in transgenic potato has recently been shown to increase the resistance of potato to fungal and bacterial pathogens, most probably because of the toxicity of $\mathrm{H}_{2} \mathrm{O}_{2}$ to these pathogens (Wu et al. 1995). However, GO-mediated cell death that could be engineered with pathogen-responsive promoters was not explored in their study. In contrast, our strategy involved generating high amounts of $\mathrm{H}_{2} \mathrm{O}_{2}$ locally in a pathogen-inducible manner. This strategy would also be beneficial in further protecting the plants if SAR could be induced in the systemic tissue via $\mathrm{H}_{2} \mathrm{O}_{2}$ generated at the infection site. Therefore, GO expression in transgenic plants was driven by a Px gene promoter isolated previously from the tropical pasture legume Stylosanthes humilis (Curtis et al. 1997). This promoter is weakly expressed in most tissues but is strongly induced by pathogens and wounding (Curtis et al. 1997). The GO gene construct also contained a signal peptide from a carrot extensin gene (Chen and Varner 1985) to mediate the secretion of GO gene product. This is expected to lead to higher expression since invertases, which generate glucose from sucrose, are known to be present in the apoplast (Fahrendorf and Beck 1990). In addition, rapid increase in invertase activity after wounding and pathogen infection (Krishnan and Pueppke 1988) could be beneficial, as it would provide glucose to $\mathrm{GO}$ when the production of $\mathrm{H}_{2} \mathrm{O}_{2}$ is most required.

Twenty independently transformed tobacco and seven canola lines were generated. GO-mediated $\mathrm{H}_{2} \mathrm{O}_{2}$ production in the primary transgenics and their kanamycin-resistant progeny were first screened qualitatively with a $\mathrm{KI} /$ starch medium and quantitatively with GO enzyme assays. In the KI/starch assay, 16 tobacco and five primary transgenic canola plants showed detectable GO expression as evidenced by the development of a characteristic purple-black color when cut leaves (Fig. 1A, B), roots, and flower organs were incubated on this medium. Tissue from untransformed control plants did not produce any color in this assay. The GO activity in the leaves of the highest expressing $T_{1}$ transgenic tobacco plants varied between 189 and $231 \mathrm{U}$ per $\mathrm{mg}$ of fresh wt (Fig. 2). GO expression in transgenic $\mathrm{T}_{1}$ canola plants was lower and varied between 58 and $88 \mathrm{U}$ per mg of fresh wt for the best expressors (Fig. 2). No GO activity was detected in the leaves of untransformed control plants. Intercellular fluid collected from the leaves of transgenic plants also showed GO activity, suggesting that the enzyme was targeted to the intercellular space. Based on these initial screenings, three tobacco (TGO-6, TGO-8, and TGO30) and two canola (CGO-1 and CGO-2) lines were selected and progeny from these plants were used for all subsequent experiments reported herein.

Transgene expression did not cause any noticeable alterations in the younger leaves of 5- to 6-week-old transgenic plants. However, necrotic regions appeared in the interveinal tissue of older leaves (third to fourth leaves from the base) of transgenic tobacco plants (Fig. 1E). Formation of necrotic lesions could be due to the availability of more substrate (glucose) for GO in the older leaves as a result of starch breakdown and remobilization of sugars before the leaves senesce. A similar phenotype associated with GO expression was the formation of anthocyanin in the lower leaves of transgenic canola lines (Fig. 1F). Additionally, all tobacco plants expressing GO exhibited varying degrees of sterility due to abortion of flowers (Fig. 1C). This phenotype was more severe in tobacco than in canola and resulted in the production of very few seed capsules. Seeds collected from these capsules were not completely filled and showed poor germinability (approximately 5 to $10 \%$ ). Flowers from the higher expressing canola line (CGO-1) also exhibited some sterility, especially when grown under high light conditions (Fig. 1D). Sterility associated with transgene expression was possibly due to strong GO expression driven by the Px promoter in the flower organs. Previous experiments conducted on tobacco (Curtis et al. 1997) and canola (Kazan et al. 1997) transformed with a Px promoter- $\beta$-glucuronidase (GUS) fusion construct had also demonstrated strong GUS expression in the flower organs of these plants. 


\section{Induction of rapid cell death in transgenic tissue.}

First, expression of GO in transgenic plants did not cause any visible cell death in young leaves in the absence of any induction. We next assessed the effect of known inducers of the Px promoter on the induction of cell death. Wounding or inoculation of leaves of transgenic tobacco plants with Cercospora nicotianae (causal agent of frog eye disease) was not effective in triggering visible cell death over that seen in con-
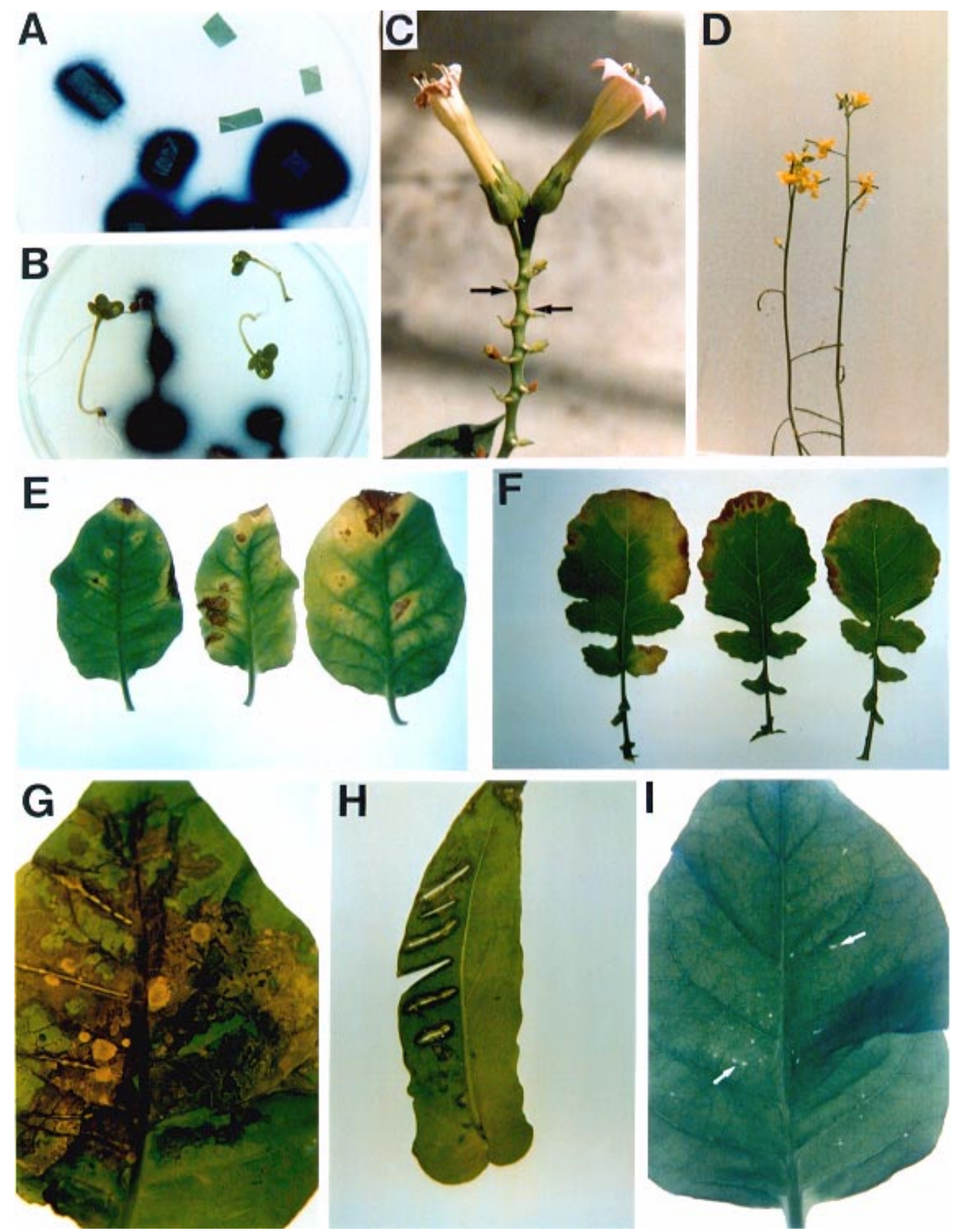

Fig. 1. Qualitative analysis of glucose oxidase (GO) expression in transgenic tissue. Leaf squares were taken from the youngest fully open leaves of (A) 6- to 8-week-old transgenic and control tobacco plants and (B) 10-day-old seedlings of transgenic and control canola plants and incubated on a KI/starch medium. Development of a purple color on this medium indicated GO expression. Sterility caused by GO expression in (C) transgenic tobacco (aborted flowers are arrowed) and (D) transgenic canola. E, Development of spontaneous necrotic lesions on lower leaves of 8-week-old transgenic tobacco (TGO-6). F, Formation of anthocyanin on lower leaves of 6- to 8-week-old transgenic canola plants (CGO-1) grown under a light intensity of $500 \mu$ mol . $\mathrm{s}^{-1} \cdot \mathrm{m}^{-2}$. Cell death induced by $20 \mathrm{mM}$ glucose $(\mathbf{G})$ on a detached and wounded (top fully open) leaf of 6-week-old transgenic tobacco (TGO-6) and (H) 4-week-old transgenic canola (CGO-1). I, Lesions (arrowed) developed $24 \mathrm{~h}$ after spray application of $1 \mathrm{mM}$ salicylic acid (SA) on a top fully open leaf of a 6-week-old transgenic tobacco plant (TGO-6). 
trol plants nor did we observe any elevation in the resistance response of transgenic tobacco against this pathogen (data not shown). However, the degree of senescence of cotyledons of transgenic canola inoculated with Leptosphaeria maculans (causal agent of blackleg disease) was much higher in transgenic plants than in untransformed control plants. In two separate experiments, approximately 400 seedlings from transgenic and control canola families were inoculated with this fungus. Degree of senescence measured visually as the percentage of plants with senescent cotyledons 10 days after inoculations ranged between 87 and 54\%, with an average value of $69 \%$ for seven transgenic canola lines, whereas control plants had an average value of $16 \%$. This response, which seems to be restricting the advent of infection to the stem, may be potentially useful for enhanced protection from this pathogen because initial infection of cotyledons has been shown to be a prerequisite of successful systemic infections (Hammond et al. 1985).

Absence of cell death in young leaves of transgenic tobacco and canola even after induction of the Px promoter by pathogens and wounding suggested that availability of glucose in plant tissue may be a factor limiting maximal GO expression. $\mathrm{H}_{2} \mathrm{O}_{2}$ levels measured in the young leaves of transgenic plants were rather low and were estimated to be in the range of 0.2 to $0.1 \mu \mathrm{mol}$ per $\mathrm{g}$ of fresh wt for TG0-6 and TGO-8 plants $\left(\mathrm{T}_{1}\right)$, respectively. To assess whether cell death can be induced in transgenic tissue by external application of a substrate, glucose $(20 \mathrm{mM})$ was supplied to detached leaves of transgenic plants through petioles. As a result, substantial amounts of $\mathrm{H}_{2} \mathrm{O}_{2}$, which were estimated to be $25 \mu \mathrm{mol}$ per $\mathrm{g}$ of fresh wt for TGO-6 and $5 \mu \mathrm{mol}$ per $\mathrm{g}$ of fresh wt for CGO-1 plants, were generated. Leaves of transgenic tobacco supplied with glucose exhibited a wilting phenotype within 12 to $24 \mathrm{~h}$. Visible lesions were also observed at this time on the treated leaves. This phenotype was not very distinctive in transgenic canola leaves treated similarly, probably due to a lower level

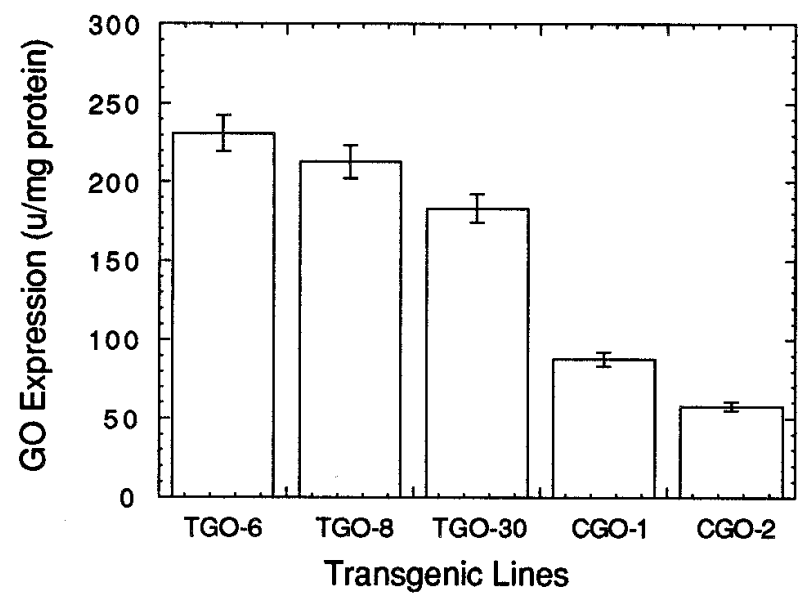

Fig. 2. Glucose oxidase (GO) activity in selected lines $\left(\mathrm{T}_{1}\right)$ of transgenic tobacco and canola. Extracts prepared from the top fully extended leaves of 4- to 6-week-old tobacco (TGO-6, TGO-8, and TGO-30) and canola (CGO-1 and CGO-2) plants. One unit of GO activity is defined as the amount that will oxidize $1.0 \mu \mathrm{mol}$ of $\beta$-D glucose to D-gluconic acid and $\mathrm{H}_{2} \mathrm{O}_{2}$ per min at $\mathrm{pH} 5.1$ and $25^{\circ} \mathrm{C}$. No GO activity was detected in the untransformed control plants. Results are given as the mean of three plants for each transgenic family. of GO expression. However, when leaves from both tobacco and canola were wounded and floated on a glucose solution for $24 \mathrm{~h}$, necrotic lesions first started at the wound sites where the Px promoter has been shown to be very active (Curtis et al. 1997) and extended rapidly to the entire interveinal area (Fig. 1G, H). Leaves from control plants floated on a glucose solution did not exhibit any visible symptom and neither did the leaves from transgenic plants floated on water. Ascorbic acid (20 to $40 \mathrm{mM}$ ) supplied with glucose completely abolished the wilting and subsequent lesion development in floated leaves, suggesting that generation of toxic radicals was responsible for the observed phenotypes. Cell death induced on transgenic plants by glucose was associated with the high level expression of the GO transgene. Hybridization signal corresponding to GO mRNA was detected in both transgenic tobacco and transgenic canola when total RNA from these leaves was extracted and analyzed on RNA gel blots (Fig. 3, upper panel). Taken together, these results suggested that the induction of cell death in transgenic tissue was possible through externally supplied glucose.

\section{Effect of SA on cell death in transgenic tobacco.}

The defense regulator SA has been suggested to potentiate the induction of HR and SAR in tobacco (reviewed by Draper 1997). We wanted to test whether SA, supplied with or without glucose, had any additional effect on cell death in transgenic tobacco leaves. When SA $(1 \mathrm{mM})$ was supplied in combination with glucose, wilting and necrotic lesions formed at a visibly faster rate than when glucose was supplied alone. In contrast, this treatment did not cause development of any visible symptoms on the leaves of untransformed plants. Spray application of SA $(1 \mathrm{mM})$ to the leaves of transformed plants caused the development of macroscopic lesions ( 1 to $3 \mathrm{~mm}$ ) on the young leaves of transgenic tobacco within $24 \mathrm{~h}$ of application (Fig. 1I), whereas no

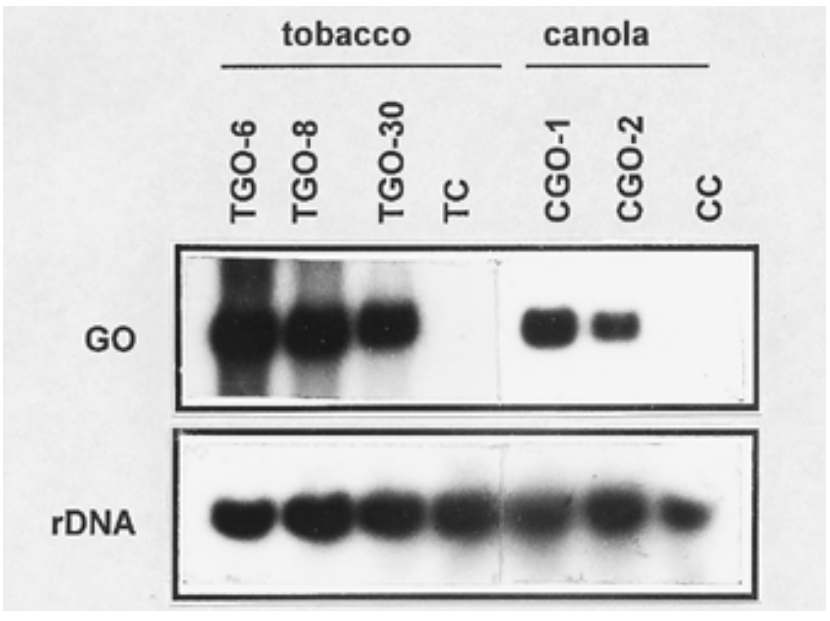

Fig. 3. Northern (RNA) blot analysis of expression of glucose oxidase (GO) in selected lines of transgenic tobacco (TGO-6, TGO-8, and TGO30) and canola (CGO-1 and CGO-2) plants (upper panel). Total RNA was isolated from top fully expanded leaves of 6- to 8-week-old transgenic $\left(\mathrm{T}_{1}\right)$ and control (TC and $\mathrm{CC}$ ) plants, run on denaturing gel and transferred to a filter. Polymerase chain reaction-amplified GO genomic clone was labeled with ${ }^{32} \mathrm{P}$ and used as hybridization probe under stringent conditions. To verify equal RNA loadings, filter was stripped and reprobed with a wheat ribosomal DNA repeat (rDNA, lower panel). 
symptom development was visible on the leaves of untransformed plants sprayed with the same dose of SA (data not shown). To quantify the effect of SA on cell death, we measured the ion leakage from the treated tobacco tissue since electrolyte loss from elicited cells or tissue is commonly used as an indicator of membrane damage and subsequent cell death (Klement 1986). Our experiments demonstrated that electrolyte loss began within a few hours in the glucose-supplied transgenic leaves and also that $1 \mathrm{mM}$ SA applied by itself had some promoting effect on ion leakage in transgenic plants. However, a combined application of glucose and SA enhanced electrolyte leakage in transgenic leaves fivefold over that measured for the control plants (Fig. 4). These results suggest that SA can further potentiate cell death, possibly by affecting AOS status of the plant tissue (Chen et al. 1993; Durner and Klessig 1996). The results are also consistent with the proposed role for SA in the generation of a sustained oxidative burst observed in plant cell cultures (Shirasu et al. 1997). Increased cell death was not due to the induction of the Px promoter used to express GO since this promoter was not responsive to SA in mature leaves (Curtis et al. 1997).

Currently, the mode of action of SA is not exactly known. However, SA has been proposed to be an activator of a plasma membrane alternative oxidase (Wagner 1995), which, upon sensing of the elicitor, is implicated in triggering HR by generating substantial amounts of AOS (Draper 1997). Furthermore, SA can stimulate $\mathrm{H}_{2} \mathrm{O}_{2}$ production by a process known as potentiation. This effect of SA has recently been shown for cultured cells of tobacco (León et al. 1995), cucumber (Kauss and Jeblick 1995), and petunia (Wagner 1995). In the presence of a fungal elicitor, potentiation mediated by SA was manifested even more strongly and caused accumulation of a substantial amount of $\mathrm{H}_{2} \mathrm{O}_{2}$ in soybean cell cultures elicited with Pseudomonas syringae pv. glycine (Shirasu et al. 1997) and in parsley cell cultures elicited with mastoparan (Kauss and Jeblick 1995). Recent evidence also shows that $\mathrm{H}_{2} \mathrm{O}_{2}$ accumu-

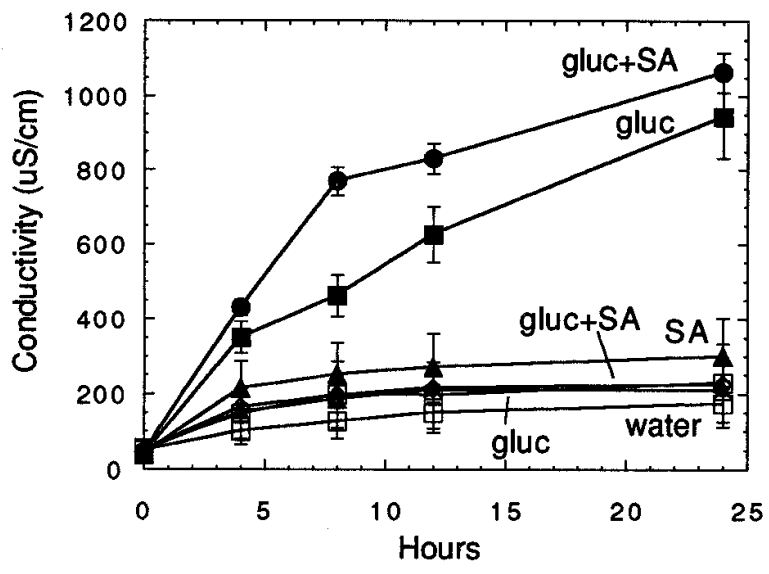

Fig. 4. Quantification of electrolyte leakage as a measure of cell death in the leaf samples taken from the 6-week-old transgenic (TGO-6) and control tobacco plants $(n=3)$. Leaves from untransformed control plants floated on water (open circles), or solutions containing $20 \mathrm{mM}$ glucose (open squares), $1 \mathrm{mM}$ salicylic acid (SA; open triangles), or $1 \mathrm{mM} \mathrm{SA}$ and $20 \mathrm{mM}$ glucose (open diamond). Leaves from transgenic plants floated on solutions containing $1 \mathrm{mM}$ SA (closed triangles), $20 \mathrm{mM}$ glucose (closed squares), or $20 \mathrm{mM}$ glucose and $1 \mathrm{mM} \mathrm{SA}$ (closed circles). lated in the tissue further stimulates SA synthesis in a positive feedback loop mechanism by activating benzoate-2hydroxylase, which is required for the synthesis of SA from benzoic acid (León et al. 1995; Draper 1997). Finally, inhibition of $\mathrm{H}_{2} \mathrm{O}_{2}$-degrading enzymes such as catalases (Chen et al. 1993) and ascorbate peroxidases (Durner and Klessig 1995) by SA could be another reason for enhanced cell death in SAtreated transgenic tissue. Indeed, whether SA positively or negatively modulates catalase activity will depend on the redox status of the cell (Durner and Klessig 1996). However, more experimental evidence is needed to clarify the mechanism of SA action in promoting cell death.

\section{Defense gene induction in transgenic tissue.}

Recently, Chen et al. (1993) have suggested that $\mathrm{H}_{2} \mathrm{O}_{2}$ acts as a second messenger in the induction of the PR-1a gene in the systemic tissue at the onset of SAR. This model assigns a central role for SA in inhibiting activity of catalases and peroxidases. As a result, $\mathrm{H}_{2} \mathrm{O}_{2}$ that escapes from degradation is implicated as a signal molecule in the activation of defense genes, particularly, PR-1a. In contrast, other studies have not indicated any connection between SAR and $\mathrm{H}_{2} \mathrm{O}_{2}$, based on evidence that $\mathrm{H}_{2} \mathrm{O}_{2}$ levels do not increase in the systemic tissue undergoing SAR (Bi et al. 1995; Neuenschwander et al. 1995). Additionally, $\mathrm{H}_{2} \mathrm{O}_{2}$ only slightly induces $\mathrm{PR}-1 \mathrm{a}$ gene expression when externally applied in very high concentrations ( $\mathrm{Bi}$ et al. 1995). To assess the role of $\mathrm{H}_{2} \mathrm{O}_{2}$ as a secondary signal for the induction of SA-dependent defense responses, we examined induction patterns of two tobacco PR genes (PR-1a and PR-5) in transgenic tobacco. Total RNA was isolated from the intact, glucose-fed, and SA-sprayed young leaves of TGO-6 plants and probed with cDNAs of two PR genes of tobacco, representing SA-induced and uninduced classes of PR proteins (acidic PR-1a and basic PR-5 or thaumatin-like protein: Ward et al. 1991; Cornelissen et al. 1986). RNA gel blot analyses demonstrated that no PR-1a mRNA was detectable in young leaves of TGO-6 plants (Fig. 5, upper panel). However, strong PR-1a induction was observed when young leaves of transgenic plants were detached and fed with $20 \mathrm{mM}$ glucose for $24 \mathrm{~h}$ before RNA isolations (Fig. 5, upper panel). This induction was comparable to the level of PR-1a mRNA induced by SA in the leaves of untransformed plants. Our results also showed that exogenously supplied glucose induced relatively low levels of induction of the PR-1a gene in the leaves of untransformed control plants (Fig. 5, upper panel). Although the PR-1a gene was induced in transgenic leaves by external glucose, it is not clear whether this induction is a direct consequence of $\mathrm{H}_{2} \mathrm{O}_{2}$ or a result of $\mathrm{H}_{2} \mathrm{O}_{2}$ mediated stress causing substantial membrane damage as revealed by electrolyte leakage measurements.

Low levels of PR-1a mRNA were detected in the older leaves of transgenic tobacco with spontaneous necrotic lesions (Fig. 5, upper panel). It is possible that the presence of necrotic spots may have some role in the induction of this gene in a way that is similar to the activation of constitutive defense responses in Arabidopsis thaliana $l s d 2$ and $l s d 4$ (lesion simulating disease) mutants and maize lesion mimic mutants (Hunt et al. 1997; Dangl et al. 1996). SA-independent and age-dependent induction of PR-1a in glucose-treated tobacco leaf disks has also been recently demonstrated by Herbers et al. (1996a). 
In contrast to the induction pattern of PR-1a, stress imposed by $\mathrm{H}_{2} \mathrm{O}_{2}$ did not appear to induce accumulation of the PR-5 transcript in glucose-fed leaves of TGO-6 plants. Induction of this gene was correlated with the presence of lesions. For instance, although treatment with SA did not directly induce this gene in control plants, the presence of macroscopic lesions caused by SA application (see Fig. 1I) in transgenic plants coincided with high-level induction. PR-5 was also highly induced in transgenic leaves with spontaneous necrotic lesions (Fig. 5, middle panel). These results were consistent with previous reports that induction of PR-5 is correlated with lesion development but that SA application is not effective on the induction of this gene (Cornelissen et al. 1986).

In conclusion, our results suggest that defense genes may be induced in GO-expressing plants but that cell damage that precedes this induction may be important for the initiation of this induction. It is also possible that activation of PR-1a is a consequence of perturbation of cell metabolism by GO expression as transgenic expression of some genes (i.e., invertases) involved in sugar metabolism is known to induce cell death and defense responses in transgenic plants (Herbers et al. 1996a). Recent results from other studies also have also suggested that superoxide ions $\left(\mathrm{O}_{2}^{-}\right)$rather than $\mathrm{H}_{2} \mathrm{O}_{2}$ regulate defense gene induction in parsley cell cultures (Jabs et al. 1997). Furthermore, $\mathrm{O}_{2}^{-}$were shown to be necessary and sufficient for induction of lesion formation and PR-1a mRNA

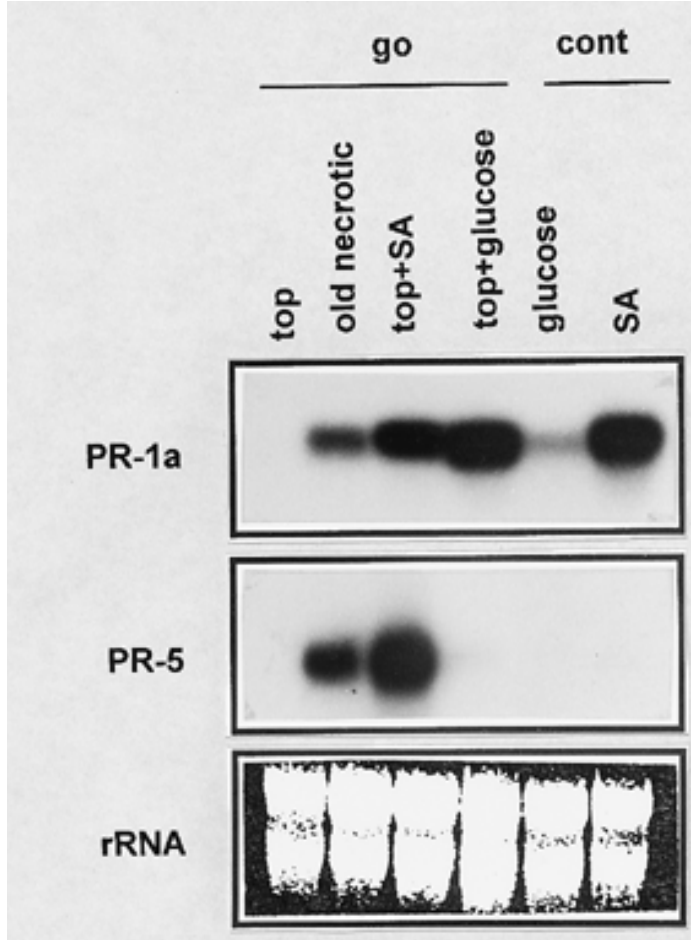

Fig. 5. Induction of mRNA of PR-1a (upper panel) and PR-5 (middle panel) genes in leaves of transgenic and control tobacco plants. Lanes 1 to 4 contain RNA isolated from the following organs of 8-week-old tobacco plants (TGO-6) transformed with a glucose oxidase (GO) gene lane 1, top fully open leaf; lane 2, lower leaf with spontaneous necrotic lesions; lane 3 , top fully open leaf sprayed with $1 \mathrm{mM}$ salicylic acid (SA); and lane 4, top fully open leaf floated on $20 \mathrm{mM}$ glucose for $24 \mathrm{~h}$. Lanes 5 and 6 contain RNA isolated from the top leaves of control plants floated on $20 \mathrm{mM}$ glucose for $24 \mathrm{~h}$ and sprayed with $1 \mathrm{mM} \mathrm{SA}$, respectively. Ethidium bromide-stained rRNA bands are shown in lower panel. accumulation in the "lesion simulating disease resistance response" mutant, lsdl, of Arabidopsis thaliana (Jabs et al. 1996). These results suggest that the induction of defense genes may be triggered by $\mathrm{O}_{2}^{-}$.

Our results also suggest some potential for the use of GO for the induction of artificial cell death in plants but exploitation of this system depends on the availability of glucose in the plant tissue and the use of more specific and stringently controlled promoters to drive the expression of GO. Coexpression of an invertase in the same subcellular compartment with GO may increase the availability of glucose but also further complicates the situation because expression of invertase in transgenic plants activates a physiological cell death program of its own by perturbing the sugar balance of the plants (Herbers et al. 1996b).

\section{MATERIALS AND METHODS}

\section{Plasmid construction and plant transformation.}

Isolation and characterization of the Taloramyces flavus GO gene has been previously described (Murray et al. 1997). A BamHI-SacI fragment containing the leader sequence of a carrot extensin gene (Chen and Varner 1985) and the coding region of GO was excised from the plasmid pCON6 (Murray et al. 1997) and used to replace the GUS coding region in binary vector pMC32 (in pPZP111 backbone; Hajdukiewicz et al. 1994), which contained the GUS coding region fused to a 500-bp fragment of a Px gene promoter isolated previously from the tropical pasture legume Stylosanthes humilis (Curtis et al. 1997). This yielded the binary vector pKKGO1, which was then transferred to Agrobacterium tumefaciens strain LBA4404 by triparental mating. This vector was used to transform tobacco (Nicotiana tabacum cv. Xanthi) and canola (Brassica napus cv. Westar) plants. Tobacco was transformed via an Agrobacterium tumefaciens-mediated leaf-disk transformation procedure by selecting for kanamycin resistance (Horsch et al. 1985). Double haploid canola line 141-227 derived from the cultivar Westar was obtained from W. D. Beversdorf of the University of Guelph and was transformed as previously described (Kazan et al. 1997). Independently transformed plants $\left(\mathrm{T}_{0}\right)$ were planted in soil and self-pollinated, and all subsequent work was performed with the progeny plants $\left(\mathrm{T}_{1}\right)$. Soil-grown plants were maintained in a controlled environment room with a 16 -h photoperiod and a light intensity of $500 \mu \mathrm{mol} \cdot \mathrm{s}^{-1} \cdot \mathrm{m}^{-2}$ with a temperature regime of 25 and $19^{\circ} \mathrm{C}$ for day and night, respectively.

\section{RNA isolations and Northern (RNA) blot analysis.}

Total RNA from tobacco and canola plants was isolated with a guanidinium thiocyanate-caesium chloride purification procedure according to Chirgwin et al. (1979). Twenty micrograms of RNA was separated on a $1.5 \%$ formaldehyde denaturing gel and blotted on a Hybond-N filter (Amersham, Buckinghamshire, England) according to the supplier's instructions. A GO genomic clone and cDNA clones of PR-1a and PR-5 (kindly provided by J. Bol) were amplified by polymerase chain reaction from the respective plasmids, labeled with ${ }^{32} \mathrm{P}$, using the Megaprime labeling kit (Amersham), and used as hybridization probes. 
GO measurements and detection of $\mathrm{H}_{2} \mathrm{O}_{2}$ in plant tissue.

For quantitative GO assays, leaf tissue taken from the top fully open leaves of high-GO-expressing transgenic lines (three leaves each) was homogenized with $0.1 \mathrm{M} \mathrm{Na}_{2} \mathrm{PO}_{4}$ buffer (pH. 6.0) in a mortar and pestle. The homogenate was poured into Eppendorf tubes and centrifuged at 13,000 rpm (Beckman J2-HS centrifuge, Eppendorf, Hamburg, Germany) for $15 \mathrm{~min}$. The supernatant was removed and incubated at $4^{\circ} \mathrm{C}$ for 2 to $3 \mathrm{~h}$ before it was assayed for GO activity according to the method given in Murray et al. (1997). One unit of GO activity is defined as the amount that will oxidize 1.0 $\mu$ mol of $\beta$-D glucose to D-gluconic acid and $\mathrm{H}_{2} \mathrm{O}_{2}$ per minute. Protein concentration was determined by the method of Bradford (1976) with a kit from BioRad (Hercules, CA) and bovine serum albumin standards. Histochemical detection and quantitative estimation of $\mathrm{H}_{2} \mathrm{O}_{2}$ generated in the transgenic leaf tissue of high-GO-expressing transgenic lines was done essentially as described by Olson and Varner (1993) and Wu et al. (1995).

\section{Application of glucose and SA and measurement of electrolyte leakage.}

Glucose and SA were supplied to young leaves taken from 4- to 5-week-old plants according to the method given in Chen et al. (1993). Briefly, SA and glucose were supplied to detached leaves of transgenic and untransformed control plants by either floating the leaves on a solution containing different concentrations $(20$ to $40 \mathrm{mM})$ of glucose (pH.6) and SA (1 $\mathrm{mM}$, pH.6) or feeding the leaves with the same solutions through the petiole. The glucose solution was changed daily to reduce any microbial infection. These leaves were kept in a growth chamber under low light intensity with a growth temperature of $22^{\circ} \mathrm{C}$. Intracellular fluid was isolated from the detached leaves treated as described above by centrifugation at $350 \times g$ for 15 min after vacuum infiltration with MilliQ water (Millipore, Bedford, MA) and used for determination of ion leakage. Conductivity measurements were taken with a conductimeter (Pharmacia, Uppsala, Sweden).

\section{Pathogen inoculations of transgenic plants.}

Seeds from primary transgenic tobacco and canola plants were germinated on basal medium with kanamycin (400 $\mathrm{mg} /$ liter for tobacco and $100 \mathrm{mg} /$ liter for canola) and only kanamycin-resistant plants were used for inoculation experiments. Four- to 5-week-old transgenic $\left(\mathrm{T}_{1}\right)$ and control tobacco plants were spray inoculated with a conidial suspension $\left(5 \times 10^{4}\right.$ spores per $\left.\mathrm{ml}\right)$ of Cercospora nicotianae, which causes frog eye disease in tobacco. Inoculated plants were incubated in a water-saturated atmosphere for $24 \mathrm{~h}$ before being returned to normal growing conditions, and were examined 7 days later for symptom development. Transgenic canola seedlings $\left(\mathrm{T}_{2}\right)$ were inoculated 10 days after sowing by puncturing cotyledons with a fine needle and applying $10 \mu \mathrm{l}$ of a pycnidiospore suspension $\left(10^{6}\right.$ spore per $\left.\mathrm{ml}\right)$ of Leptosphaeria maculans (blackleg disease pathogen) to the wound. Plants were incubated under a temperature regime of $21^{\circ} \mathrm{C}$ day and $19^{\circ} \mathrm{C}$ night with 16-h daylength. Control seedlings came from $\mathrm{T}_{1}$ segregants lacking the GO gene. Seedlings were examined 10 days after inoculation and lesion development was scored on the 1 to 9 scale of severity, using the scheme of Williams (1985).

\section{ACKNOWLEDGMENTS}

We thank J. Bol for providing the PR-1a and PR-5 cDNA probes, R. D. Beversdorf for double haploid canola lines, and P. Trevorrow for the Cercospora nicotianae isolate. We acknowledge the help provided by Heather Way with the plant disease inoculations. This study was supported by grants from Grains Research and Development Corporation and Cotton Seed Distributors.

\section{LITERATURE CITED}

Apostol, I., Heinstein, P. F., and Low, P. S. 1989. Rapid stimulation of an oxidative burst during elicitation of cultured plant cells. Plant Physiol. 90:109-116.

Baker, C. J., and Orlandi, E. W. 1995. Active oxygen in plant pathogenesis. Annu. Rev. Phytopathol. 33:299-321.

Baker, C. J., Orlandi, E. W., and Mock, N. M. 1993. Harpin, an elicitor of the hypersensitive response in tobacco caused by Erwinia amylovora, elicits active oxygen production of suspension cells. Plant Physiol. 102:1341-1344.

Bi, Y.-M., Kenton, P., Mur, L., Darby, R., and Draper, J. 1995. Hydrogen peroxide does not function downstream of salicylic acid in the induction of PR protein expression. Plant J. 8:235-245.

Bradford, M. 1976. A rapid and sensitive method for quantities of protein utilizing the principle of protein-dye binding. Anal. Biochem. 72: 248-254.

Bradley, D. J., Kjellbohm, P., and Lamb, C. J. 1992. Elicitor-induced and wound-induced oxidative cross-linking of a proline rich plant cell wall protein: A novel, rapid defense response. Cell 70:21-30.

Chamnongpol, S., Willekens, H., Langebartels, C., Van Montagu, M., Inze, D., and Van Camp, W. 1996. Transgenic tobacco with a reduced catalase activity develops necrotic lesions and induces pathogenesisrelated expression under high light. Plant J. 10:491-503.

Chen, J., and Varner, J.E. 1985. An extracellular matrix protein in plants: Characterization of a genomic clone for carrot extensin. EMBO J. 4:2145-2151.

Chen, Z., Silva, H., and Klessig, D. F. 1993. Active oxygen species in the induction of plant systemic acquired resistance by salicylic acid. Science 162:1883-1886.

Chirgwin, J. M., Przybyla, A. E., MacDonald, R. J., and Rutter, W. 1979. Isolation of biologically active ribonucleic acid from sources enriched in ribonuclease. Biochemistry 18:5294-5299.

Conrath, U., Chen, Z., Ricigliano, J. R., and Klessig, D. F. 1995. Two inducers of plant defense responses, 2,6 dichloroisonicotinic acid and salicylic acid, inhibit catalase activity in tobacco. Proc. Natl. Acad. Sci. USA 92:7143-7147.

Cornelissen, B. J. C., Hooft van Huijsduijnen, R. A. M., and Bol, J. F. 1986. A tobacco mosaic virus-induced tobacco protein is homologous to the sweet tasting protein thaumatin. Nature 321:531-532.

Curtis, M. D., Rae, A. L., Rusu, A. G., Harrison, S. J., and Manners, J. M. 1997. A peroxidase gene promoter induced by phytopathogens and methyl jasmonate in transgenic plants. Mol. Plant-Microbe Interact. 10:326-338.

Dangl, J. L., Dietrich, R. A., and Richberg, M. H. 1996. Death don't have no mercy: Cell death programs in plant-microbe interactions. Plant Cell 8:1793-1807.

Desikan, R., Hancock, J. T., Coffey, M. J., and Neill, S. J. 1996. Generation of active oxygen in elicited cells of Arabidopsis thaliana is mediated by a NADPH oxidase-like enzyme. FEBS Lett. 382:213-217.

Devlin, W. S., and Gustine, D. L. 1992. Involvement of the oxidative burst in phytoalexin accumulation and the hypersensitive reaction. Plant Physiol. 100:1189-1195.

Doke, N., and Ohashi, Y. 1988. Involvement of an $\mathrm{O}_{2}^{-}$generating system in the induction of necrotic lesions on tobacco leaves infected with tobacco mosaic virus. Physiol. Mol. Plant. Pathol. 32:163-175.

Draper, J. 1997. Salicylate, superoxide synthesis and cell suicide in plant defense. Trends Plant Sci. 2:162-165.

Durner, J., and Klessig, D. F. 1995. Inhibition of ascorbate peroxidase by salicylic acid and 2,6-dichloroisonicotinic acid, two inducers of plant defense responses. Proc. Natl. Acad. Sci. USA 92:11312-11316.

Durner, J., and Klessig, D. F. 1996. Salicylic acid is a modulator of tobacco and mammalian catalases. J. Biol. Chem. 271:28492-28501.

Fahrendorf, T., and Beck, E. 1990. Cytosolic and cell-wall bound acid 
invertases from leaves of Urtica dioicia L.: A comparison. Planta 180: 237-244.

Hajdukiewicz, P., Svab, Z., and Maliga, P. 1994. The small, versatile $p$ PZP family of Agrobacterium binary vectors for plant transformation. Plant Mol. Biol. 25:989-994.

Hammond, K. E., Lewis, B. G., and Musa, T. M. 1985. A systemic pathway in the infection of oilseed plants by Leptosphaeria maculans. Plant Pathol. 34:557-565.

Herbers, K., Meuwly, P., Frommer, W. B., Métraux, J.-P., and Sonewald, U. 1996a. Systemic acquired resistance mediated by the ectopic expression of invertase: Possible hexose sensing in the secretory pathway. Plant Cell 8:793-803.

Herbers, K., Meuwly, P., Métraux, J.-P., and Sonnewald, U. 1996b. Salicylic acid-independent induction of pathogenesis related protein transcripts by sugar is dependent on leaf development stage. FEBS Lett. 397:239-244

Horsch, R. B., Fry, J. E., Hoffman, N. L., Eichholtz, D., Rogers, S. G., and Fraley R. T. 1985. A simple and general method for transferring genes into plants. Science 227:1229-1231.

Hunt, M. D., Delaney, T. P., Dietrich, R. A., Weymann, K. B., Dangl, J. D., and Ryals, J. A. 1997. Salicylate-independent lesion formation in Arabidopsis $l s d$ mutants. Mol. Plant-Microbe Interact. 10:531-536.

Jabs, T., Dietrich, R. A., and Dangl, J. L. 1996. Initiation of runaway cell death in an Arabidopsis mutant by extracellular superoxide. Science 273:1853-1856

Jabs, T., Tschöpe, M., Colling, C., Hahlbrock, K., and Scheel, D. 1997. Elicitor-stimulated ion fluxes and $\mathrm{O}_{2}^{-}$from the oxidative burst are essential components in triggering defense gene activation and phytoalexin synthesis in parsley. Proc. Natl. Acad. Sci. USA 94:4800-4805.

Jones, A. M., and Dangl, J. F. 1996. Logjam at the Styx: Programmed cell death in plants. Trends Plant Sci. 1:114-119.

Kazan, K., Curtis, M., Goulter, K., and Manners, J. M. 1997. Agrobacterium tumefaciens mediated transformation of double haploid canola (Brassica napus L.) lines. Aust. J. Plant Physiol. 24:97-102.

Kauss, H., and Jeblick, W. 1995. Pretreatment of parsley suspension cultures with salicylic acid enhances spontaneous and elicited production of $\mathrm{H}_{2} \mathrm{O}_{2}$. Plant Physiol. 108:1171-1178.

Klement, Z. 1986. Hypersensitivity. Pages 149-177 in: Phytopathogenic Prokaryotes. M. S. Mount and G. H. Lacy, eds. Academic Press, New York
Krishnan, H. B., and Pueppke, S. G. 1988. Invertases from rust-infected wheat leaves. Plant. Physiol. 133:336-339.

León, J., Lawton, M. A., and Raskin, I. 1995. Hydrogen peroxide stimulates salicylic acid biosynthesis in tobacco. Plant Physiol. 108 1673-1678.

Levine, A., Pennell, R. I., Alvarez, M. E., Palmer, R., and Lamb, C. 1996. Calcium-mediated apoptosis in a plant hypersensitive disease resistance response. Curr. Biol. 6:427-437.

Levine, A., Tenhaken, R., Dixon, R., and Lamb, C. 1994. $\mathrm{H}_{2} \mathrm{O}_{2}$ from the oxidative burst orchestrates the plant hypersensitive disease resistance responses. Cell 79:583-593.

Low, P. S., and Merida, J. R. 1996. The oxidative burst in plant defense: Function and signal transduction. Physiol. Plant. 96:533-542.

Mehdy, M. C. 1994. Active oxygen species in plant defense against pathogens. Plant Physiol. 105:467-472.

Murray, F. R., Llewellyn, D. J., Peacock, W. J., and Dennis, E. S. 1997. Isolation of the glucose oxidase gene from Talaromyces flavus and characterization of its role in the biocontrol of Verticillium dahlia. Curr. Genet. 32:367-375.

Neuenschwander, U., Vernooij, B., Friedrich, L., Uknes, S., Kessmann, H., and Ryals, J. 1995. Is hydrogen peroxide a second messenger of salicylic acid in systemic acquired resistance? Plant J. 8:227-233.

Olson, P. D., and Varner, J. E. 1993. Hydrogen peroxide and lignification. Plant J. 4:887-892.

Shirasu, K., Nakajima, H., Krishnamachari, R., Dixon, R. A., and Lamb, C. 1997. Salicylic acid potentiates an agonist-dependent gain control that amplifies pathogen signals in the activation of defense mechanisms. Plant Cell 9:261-270.

Wagner, A. M. 1995. A role for active oxygen species as second messengers in the induction of alternative oxidase gene expression in $\mathrm{Pe}$ tunia hybrida cells. FEBS Lett. 368:339-342.

Ward, E. R., Uknes, S. J., Williams, S. C., Dincher, S. S., Wiederhold, D. L., Alexander, D. C., Ahl-Goy, P., Métraux, J. P., and Ryals, J. 1991. Coordinate gene activity in response to agents that induce systemic acquired resistance. Plant Cell 3:1085-1094.

Williams, P. H. 1985. Resource Book. Crucifer Genetics Cooperative. Department of Plant Pathology, University of Wisconsin, Madison.

Wu, G., Shortt, B. J., Lawrence, E. B., Fitzsimmons, K. C., and Shah, D. M. 1995. Disease resistance conferred by expression of a gene encoding $\mathrm{H}_{2} \mathrm{O}_{2}$-generating glucose oxidase in transgenic potato plants. Plant Cell 7:1357-1368. 